\title{
Characterization of Conch Shell Nanoparticles (Shanka Bhasma) Synthesized by the Classical Method
}

\author{
Sanwal Savita ${ }^{1}$, Yadav Yadevedra ${ }^{2 *}$, Sharma Usha ${ }^{3}$, Rawat Sushma ${ }^{4}$, Sharma Khemchand ${ }^{5}$ \\ ${ }^{1}$ P.G Scholar, ${ }^{2}$ Assistant Professor, ${ }^{3,4}$ Associate Professor, ${ }^{5}$ Professor and Head, P G Deptt of RS \& BK, Uttarkhand Ayurved University, Rishikul \\ Campus, Haridwar, India 249401
}

DOI: $10.36348 /$ sijtcm.2020.v03i05.002

| Received: 03.04.2020 | Accepted: 10.04.2020 | Published: 17.05.2020

*Corresponding author: Dr. Yadevendra Yadav

\section{Abstract}

Shankha (Conch) is one of member of Sudha varga (A class of calcium containing compound). It is used in various stomach ailments from many centuries. Shankha Bhasma (Conch Ash) is chief ingredient of many formulations. Physical and chemical characterization is fundamental step to understand the importance of determining efficacy and evaluating the clinically approved medicines of Tradition and complementary medicine (TCM). The physical characterization of Conch Ash was done by using X-ray diffraction (XRD), Scanning Electron Microscopy (SEM-EDX), and Fourier Transform Infra-red (FTIR) and particle size analysis by sieving technique and composition of heavy metals and its limits was determined using by Atomic absorption spectroscopy (AAS). For chemical characterization pH, Loss on drying, total ash, Acid insoluble ash, Water soluble ash was performed. The results revealed that Bhasmikarana (Incineration) process use in preparation ultimately changes the most stable polymorph of calcium carbonate of Shankha aragonite form into calcite from, along with formation of Portlandite and Lime in majority. FTIR spectra also confirm this assertion. Cubiclike calcite crystals of Conch Ash and rod-like aragonite crystals of conch shell powders were observed by SEM. The prepared formulation has nanoparticles with the average particle size ranging from to 62-90 nm as estimated using SEM and crystal size analysis by XRD.

Keywords: Shankha, Bhasma, Conch Ash, Shikarkhar Gajputa, Aragonite, Calcite.

Copyright @ 2020: This is an open-access article distributed under the terms of the Creative Commons Attribution license which permits unrestricted use, distribution, and reproduction in any medium for non-commercial use (NonCommercial, or CC-BY-NC) provided the original author and source are credited.

\section{INTRODUCTION}

Herbs and mineral obtained from natural origins have been extensively employed in Ayurvedic formulations [1]. Animal product and by-product are also an integral part of Ayurvedic pharmaceutics. Marine by-products like conches, pearls, mother of pearl shells and corals have been used in Ayurvedic medicine for centuries.[2] Shankha is a conch shell of religious and ritual importance in Buddhism and Hinduism. It is the shell of a large predatory sea snail, Turbinella pyrum, Turbinella rapa or Xanchus pyrum found in the Indian Ocean. Shankha (Conch) is a member of Mollusc's largest class- Gastropoda, familyTurbinellidae. These molluscs are enclosed in a shell and the shell is very hard \& dense calcareous structure. The overall dimension of the main body of the shell is conical or oblong. In the oblong form, it has a bulging in the middle portion but conical at each end. The upper portion (the siphonal canal) is corkscrew-shaped, while the lower end (the spire) is tapering and twisted. Its colour is dull, and the surface is brittle, hard and translucent. Like all snail shells, the interior is hollow.
The inner surfaces of the shell are gleaming, but the outer surface exhibits high tuberculation [3]. In its earliest references, Shankha is mentioned as a trumpet and in this form, it became an emblem of Vishnu [4]. Based on its direction of coiling, the Shankha has two varieties (i) Vamavarta ("left-turned" as viewed with the aperture uppermost): best and rear, use in a religious context (ii) Dakshinavarta Shankha commonest and use in Marana (incineration) [5]. Shankha is used in Ayurveda medicinal formulations to treat many ailments. Shankha Bhasma (Conch Ash) is commonly prepared from Conch shell which is mentioned in several Ayurvedic literatures [6]. Shankh Bhasma derived is an Ayurvedic formulation popularly used for the treatment of [7] GIT ailments, because it has, has Sheetal (cooling), Kshariya (alkaline), Grahi (adsorbent) and Vishahara (detoxifying) properties. Its Bhasma is white and is alkaline. It is used in the treatment of Amlapitta (Dyspepsia), Agnimand (Loss of Appetite), Parinam Shula (Peptic ulcer), Grahini (Ulcerative colitis), Tarunyapedika (Acne vulgaris) and Netrpusphahara 
(eye infections). Maximum dose of this Bhasma is 250 $\mathrm{mg}$ [8]. It is an important ingredients of many preparations like Pravalpanchamirta Rasa, Kaphaketu Rasa, Shankha Vati and Chandrodaya Varti, et al. [9]. It is prepared as Shankha Nabhi (Inner conch shell) Ash, known in Sanskrit as Shankha Bhasma, which is prepared by soaking the shell in the lime juice (Citrus limon L.), Jayanti Swarasa (Sesbania sesban), Tanduliyak Swarasa (Amaranthus viridis) or Kanji and boils for 4 pehara (12 hrs) [8]. The obtained intermediate preparation is triturated with the pulp of Ghrut-kumari leaf (Aloe vera) then calcination in covered earthen crucibles, 2 times, and finally reducing it to powder ash. It provides a good supplementation of calcium as properly manufactured Bhasma (Ash) contains $61.36 \%$ of the calcium in the form of $\mathrm{CaCO} 3$, which was the first antacid known to be used. The different unit operative employed in preparation of the Bhasmas (Ash) includes specifications for products including the use of particular raw-materials and reagents. These operation and intermediate media are responsible for the addition of medicinal value in the initial raw drug. Bhasma is a preparation of metal and mineral goes through various specified processes describing the time durations for trituration treatments and calcinations procedures. Although, these specifications of the systematic methodology of preparation. There are very few scientific documents for explanations of these long procedures of preparation [10]. Characterization is an essential part of pharmaceutical science, refers to general process by which a material's structure and properties are probed and measured. Therefore, it is a fundamental process in drug development without which no scientific explaination of drug action could be ascertained [11]. SOP and Protocol testing is mention in Ayurvedic Formulary of India [7]. However, microscopic characterization is still required to understand the pharmacological aspect of medicine and also to understand the identity, purity and strength of the product. This study has also established the standard operating procedure (SOP), and established the Inprocess quality control (IPQC) and finished product quality control (FPQC) for quality Assurance (QA).

\section{MATERIALS AND METHOD Preparation of the formulation}

Procurement and authentication of raw material and processing media: Raw Shankha was collected from the Kharibavari market, Delhi was identified by experts of P.G Department of Rasa Shastra \& Bhaishajya Kalpana, Uttrakhand Ayurved University, Rishikul Campus Haridwar, and India. Nimbu (Citrus limon L.) was purchased from the local market of Haridwar.

\section{Preparation of Shankha Bhasma (Incinerated Conch)}

In Rasa Shastra (Iatrochemistry) the whole processing of Bhasma Nirman (Incineration) was be divided into two processes namely, first is Shodhana (Purification) and final is Marana (Incineration). Thus, here this methodology is also adopted.

\section{Purification of Conch}

Shodhana [12] process for Conch was carefully chosen from the textbook of Rasa Tarangini [8] First of all, Nimbu Swarasa (Lemon juice) was prepared by the mechanical method of extraction from fresh lemon employed by kitchen lemon squeezer and screened off the seeds and fibrous pulp through SS strainer. Small pieces of conch shell were made by crushing into the iron pounding instrument. A Pottali (Bag) was made by keeping these pieces in a double fold muslin cloth. This bag was hanged in the S.S. vessel with the support of wooden stick with special care to avoid touching its bottom and liquid media, i.e., clarified lemon juice was poured into the vessel until the bag was entirely dipped in it. Then the vessel was kept over the gas stove at medium flame. This arrangement is called "Dola Yantra" and the procedure is called Swedana (Steam baking). The process was continued for 12 hours; during the operation, a frequently small amount of lemon juice was added in the vessel in order to maintain the level of lemon juice. After this, the bag was opened and the Conch shell pieces were taken out and thoroughly cleaned with lukewarm water and dried.

\section{Marana}

Mardan is the very tedious operation, and it can be divided into 3 phases viz Bhawana (Levigation in specified media)[13], Chakarika-Nirman (pelletization), Puta (traditional method of Incineration in a pit)[14]. In this practice mixture of purified raw material i.e, Conch (800gm) and stated amount of liquid media is levigated in a black stone mortar with the help of pestle until its consistency change into a thick paste, suitable for preparing Chakrikas (pellets), then pellets are made and spread on the plastic sheet for sun drying. After proper drying of pellets, they are weighed, and Sharavasamputa (sealing of pre-filled earthen saucer) was done with the help of two Sharava (earthen saucer), and the junction was sealed by double-folded mud-smeared muslin cloth and again allowed for complete drying. Then it was subjected to "Putapaka". Generally in the Marana (Incineration) process of counch shell, Gajuputa is mentioned in almost all texts. The classical reference of the dimension of Gaja Puta's pit was taken from Rasa Ratna Samuchhaya i.e., one "Rajahasta Pramana" (30 angulas $=57 \mathrm{~cm}$ ) in all axis. Shikharakar Gajaputa was selected for Marana of Shankha as it was mentioned as the best in "Vijnanabodhini" Hindi commentary of Dattatreya Anant Kulkarni on Rasa Ratana Sammuchya [15]. Generally, the Upalas (Dry cow dung cake) was filled up to the upper margin of the Gaja Puta's pit, while in Shikharakar Gajaputa some more Upalas were arranged above the open surface of the pit in a Shikharakar (mountain-shaped) apperance. 
Shuddha shankha (779 gms) was divided into two parts and kept in two Sharava (Earthen saucer) which was covered by another similar size of an earthen saucer. Sandhibandhan (sealing) of the earthen saucer was done with wet Multani Mitti (Fine Clay) and a muslin cloth. Earthen saucer was kept in the sunlight for drying of Sandhibandhan and was subjected to incineration. Kept cow dung cake up to $2 / 3^{\text {rd }}$ depth of the pit, Sharavsamput (mud smear sealed earthen pot) was placed over it then a previously ignited cow dung cake was placed. At the same time remaining $1 / 3^{\text {rd }}$ of pit was filled with cow dung cake was quickly pile up in a pit to made tetrahedral shape. The pit was filled with $50 \mathrm{Kg}$ cow dung cake. Temperature changes during the operation were monitored by employing a K-type thermocouple thermometer during the entire process. The earthen saucers were taken out after self-cooling; its Kapadmitti (seal) was removed. Counch pieces were taken out, weighed (594 gm) and powdered in a stone mortar till fineness was attained. The powder was again triturated with lemon manually for 8 hours. When semi-solid mass was formed, Chakrika (pellets) were made. These pellets were allowed to dry for 12 hours. Pellets were weighed and again subjected to incineration, by previously mentioned mannar. The process was repeated twice in the same way. After $3^{\text {rd }}$ incineration, pellets were weighed and subjected to trituration without adding any lemon juice, to get a fine powder of Shankha Bhasma $(517 \mathrm{gms})$, which is finished formulation. The A.F.I part I, advises to give only two Putas for the Shankha Marana [7]. In the present study, three Shikhrakar puta was given for the conch. After the third put, the Bhasma became finer and white.

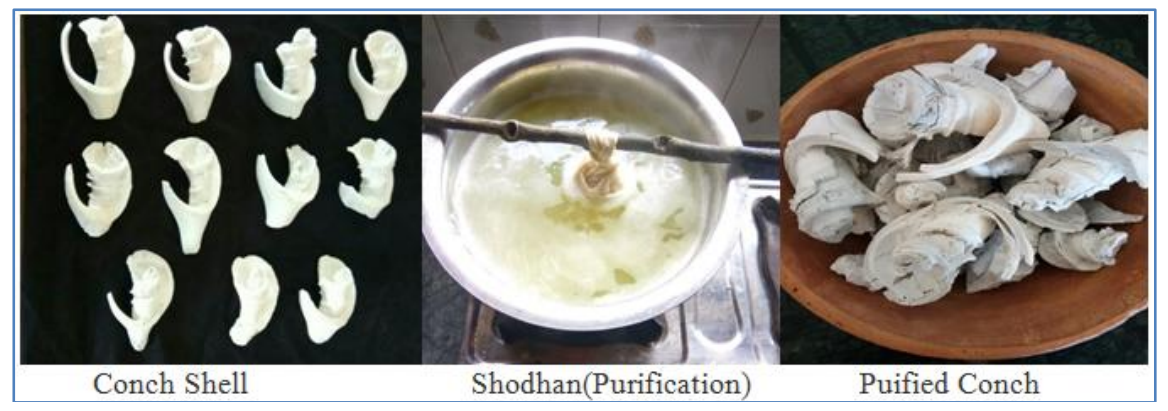

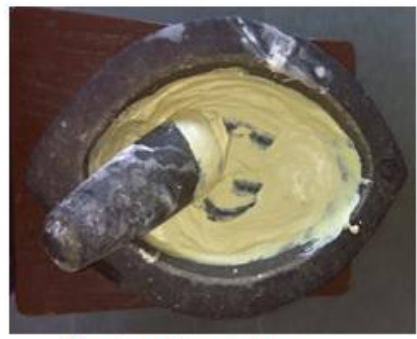

Levigation process

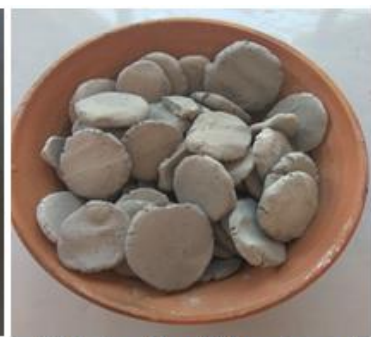

Pellets after $2^{\text {nd }}$ incineration

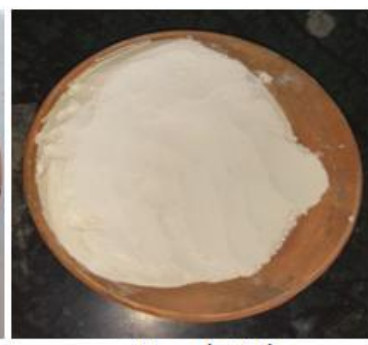

Conch Ash

Fig-1: Different samples and processes of Preparation of conch Ash

\section{Characterization techniques used analysis of sample Bhasma Pariksha}

Various traditional methods of Finishedproduct quality control (FPQC) methods of Bhasma analysis are still in practice of Rasa Shastra and have valuable importance due to very easy to perform, economical and time-saving. The carried out test were as; (a) Varna [Color], (b) Rekhapurnata - When Bhasma is spread between the index finger and thumb and rubbed, it should be so fine as to get easily into the lines and crevices of the fingers and should not be washed out from the lines of the fingers and (c) Slakshnatvum It is a tactile sensation produced by Bhasma simply by touch with fingertips [16].

\section{Organoleptic properties}

It is a fundamental test used in the food and pharmacy sector, such as appearance (colour), touch, taste, odour [17].

\section{Physico-chemical analysis}

This was carried out to know the particular chemical nature of the raw and final product and to point out the Physico-chemical changes and effect of different Samaskaras (Pharmaceutical operation) during the pharmaceutical processing. The entire analysis was done on the finished formulation of the conch, i.e., Shankha Bhasma. The following prescribed pharmacopoeia protocols testing of physico-chemical parameters namely were done [18]. (i) pH, (ii) Loss on drying, (iii) Total ash, (iv) Acid insoluble ash (v) Water-soluble ash (vi) Qualitative and Quantitative analysis - complexometric titration by EDTA. (vii) Particle size determination by sieving method[19] (viii) Heavy Metal Analysis by Atomic absorption spectroscopy (AAS) [20] - (a) Lead : [1000 ppm, 1ppm, 5 ppm, 10ppm Pb Standard solution, $\lambda=283.3 \mathrm{~nm}]$; (b) Cadmium : [1000 ppm Cd Standard solution,$\lambda=288.8$ 
$\mathrm{nm}]$; (c) Mercury : [0.1 ppm Hg Standard solution, Mercury analyzer or Cold vapour AAS]; (d) Arsenic [2.5 ppm, $5.0 \mathrm{ppm}, \& 10 \mathrm{ppm}$ standard solution, gutzeit method]

\section{X-ray crystallographic diffraction}

Phase composition and crystalline size of the raw powdered Conch, purified Conch and incinerated Conch were analyzed through XRD studies performed on Bruker D8 Advance using X-ray (40 KV, $15 \mathrm{~mA})$ filter on target $\mathrm{Cu} K \alpha$ radiation $(\lambda=1.5418 \AA)$. XRD patterns were recorded in the $2 \theta$ range $5-90^{\circ}$ at a scanning rate of $6^{\circ} / \mathrm{min}$ in continuous mode. During working analysis distance of $10 \mathrm{~mm}$ is fixed, chamber pressure $<2.2 \times 10^{-4}$ torr. The resulted in XRD patterns were analyzed using X Powder 12 software with the aid of the ICDD PDF 2 database.

\section{Scanning Electron Microscopy- EDX}

Morphology and structure of particle were characterized via a JSM-6360L V scanning electron microscope (SEM) equipped with energy-dispersive $\mathrm{X}$ ray (EDS). The crude Conch and purified Conch were powdered in an iron mortar and sieved through 200\# mesh (75 microns), and incinerated conch was used as it is. Samples were prepared by spreading the powder sample on a double-sided carbon tape and sputtercoated with gold for nullifying the charging effect. All samples were observed with various magnifications.

\section{Fourier Transform Infra-Red spectroscopy}

All the three batches of incinerated conch were analysed on Bomem FTIR spectrophotometer (Model: MB 102) under Attenuated Total Reflection (ATR) mode with scanning range in mid-IR from wavenumber 4000-600 $\mathrm{cm}^{-1}$. Several scans recorded were \% Transmission mode with resolution. The sample was good ground and thoroughly mixed to homogenize them. The homogenized sample was mixed with dry $\mathrm{KBr}$ in 1:100 mass ratios and pellets were pressed at 5 Tons. The spectra of the sample pellets were recorded by using pure $\mathrm{KBr}$ pellet as the blank.

\section{RESULTS AND OBSERVATION}

Preparation of Formulation: Quantity of lemon and their juice used \& yield is depicted in table 1. Weight of initial quantity of conch, weight loss during purification is mention table 2. During purification temp was maintained $98^{\circ} \mathrm{C}$ throughout the experiment.

\section{Shodhana}

Table-1: Parameter and specification for lemon juice extraction

\begin{tabular}{|c|c|}
\hline Parameter of lemon juice & Measurements \\
\hline Weight of lemons & $72 \mathrm{~kg}$ \\
\hline Volume of juice & $13 \mathrm{~L}$ \\
\hline Average yield of Juice & $5.54 \mathrm{~kg} / \mathrm{L}$ \\
\hline $\mathrm{pH}$ of Juice & $2-2.5$ \\
\hline Initial quantity of juice & $5 \mathrm{~L}$ \\
\hline Additional amount of juice to maintain level of vessel & $8 \mathrm{~L}$ \\
\hline
\end{tabular}

Table-2: Parameter and specification for purification of conch

\begin{tabular}{|c|c|c|c|}
\hline Wt of Conch before purification & Wt of Conch after purification & Duration & Loss \\
\hline $800 \mathrm{gm}$ & $779 \mathrm{gm}$ & $12 \mathrm{hrs}$ & $21 \mathrm{gm}(2.66 \%)$ \\
\hline
\end{tabular}

Marana: All observations of Maran is presented in table 3.

Table-3: Parameter and specification for Marana

\begin{tabular}{|c|c|c|c|c|c|}
\hline No of puta & Amount of lemon juice & \multirow{2}{*}{ Maximum Temp. } & \multicolumn{3}{|c|}{ Weight of conch } \\
\cline { 3 - 5 } & & & before Puta & after Puta & Loss after puta \\
\hline $1^{\text {st }}$ puta & Nil & $1007^{\circ} \mathrm{C}$ & $779 \mathrm{gm}$ & $594 \mathrm{gm}$ & $185 \mathrm{gm}(23.74 \%)$ \\
\hline $2^{\text {nd }}$ puta & $6 \mathrm{~L}$ & $1012^{\circ} \mathrm{C}$ & $693 \mathrm{gm}$ & $563 \mathrm{gm}$ & $130 \mathrm{gm}(18.75 \%)$ \\
\hline $3^{\text {rd }}$ puta & $5 \mathrm{~L}$ & $1006^{\circ} \mathrm{C}$ & $622 \mathrm{gm}$ & $517 \mathrm{gm}$ & $105 \mathrm{gm}(16.88 \%)$ \\
\hline \multicolumn{4}{|c|}{ Total Loss } & $262 \mathrm{gm}(33.63 \%)$ \\
\hline
\end{tabular}

\section{Bhasma Pariksha}

Obtained Bhasma (Ash) was pearly white, particles of Bhasma filled between the furrows of fingers and very smooth \& soft.

\section{Organoleptic properties}

Prepared conch Bhasma was white; smooth \& soft in touch; the taste is Madur (Sweet) and Kashya (Astringent) and odourless powder. 
Physico-chemical Analysis: [21]

(i) $\mathbf{p H}:$ :Acidic/Alkaline nature of the substance can be determined by $\mathrm{pH}$, and in this present study, the nature of conch ash was more basic (12.8) than raw Conch shell(9.05).

(ii) Loss on drying : LOD/Moisture content of conch ash was $0.45 \%$ detected by this method

(iii) Total Ash: TA value indicates that the quantity of non-volatile inorganic material present in the drug. Ash value involves oxidation of component. It gives a percentage of inorganic constituents of the sample. Total ash value of conch ash was $37.29 \%$.

(iv) Acid insoluble ash: AIA value of the sample was the amount of ash insoluble in dilute $\mathrm{HCl}$.
Acid insoluble ash of conch Ash in the present study was $0.96 \%$. which is within an acceptable limit of Pharmaceutical standardization of Indian Medicine (PSIM).

(v) Water-soluble ash: WSA value of the sample is the amount of ash soluble in water. Watersoluble ash of Shankha Bhasma in the present study is $3.02 \%$.

(vi) Qualitative and Quantitative analysis: The qualitative analysis indicated that calcium was present in Conch Ash. [22]

(vii) Particle Size: The screening of grain size analysis of Conch Ash was done by sieving through four different numbers of sieves. The degree of fineness of a powder is differentiated and express by the particle size of the aperture of mesh of the sieve by which they pass.

Table-4: Particle size detection of Conch Ash by Sieving

\begin{tabular}{|c|c|}
\hline Percentage of Conch Ash Particle Pass through the Sieve & Mesh No. \\
\hline 100 & 20 \\
\hline 100 & 40 \\
\hline 99.58 & 80 \\
\hline 96.19 & 100 \\
\hline
\end{tabular}

\section{Assay for heavy metals}

In the heavy metal analysis of Conch and Conch Ash was performed by Atomic Absorption
Spectroscopy. Values of all heavy findings is shown if table 5.

Table-5: Heavy Metal Analysis by AAS method

\begin{tabular}{|c|c|c|c|}
\hline Name of Metal & Normal permissible limit & Conch & Conch Ash \\
\hline Lead & $10 \mathrm{ppm}$ & Not Detected & $0.884 \mathrm{ppm}$ \\
\hline Cadmium & $0.3 \mathrm{ppm}$ & $0.092 \mathrm{ppm}$ & $0.131 \mathrm{ppm}$ \\
\hline Mercury & $1 \mathrm{ppm}$ & $0.014 \mathrm{ppm}$ & $0.166 \mathrm{ppm}$ \\
\hline Arsenic & $3 \mathrm{ppm}$ & $0.033 \mathrm{ppm}$ & $0.069 \mathrm{ppm}$ \\
\hline
\end{tabular}

Results of XRD Analysis: Phase Identification: XRD analysis of all samples shows that it was calcium carbonate having chemical formula $\mathrm{CaCO}_{3}$, but various steps followed in the formulation attributed the change in the molecular structure. Raw Shanka and Shudha Shanka was Argonite (99.9) in primary phase \& compound detected in minor phase was in very minute quantity and not reliable. While, Shanka Bhasma has three compounds in it, namely are as Calcite (78.7\%) in major Phase, Portlandite (10.7) \& Lime (4.4) and in minor phase.

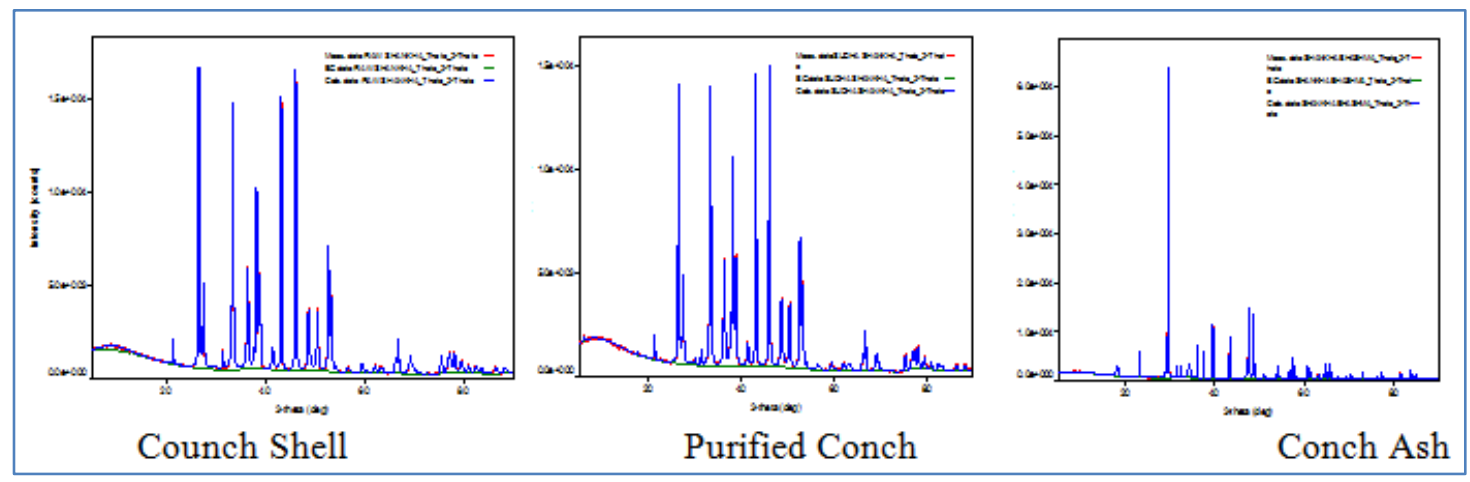

Fig-2: XRD Graph of all samples of Conch 
Table-6: Different Phases of Conch sample

\begin{tabular}{|c|c|c|c|c|}
\hline \multirow[t]{2}{*}{ Sample } & \multicolumn{4}{|c|}{ Compounds identified \& its phase } \\
\hline & Major Phase & ICDD No. & Minor Phase & ICDD No. \\
\hline Raw Shankha & Argonite $\left\{\mathrm{CaCO}_{3}\right\}$ & $10-075-9982$ & $\begin{array}{l}\text { Potassium Iron Tungsten Oxide Hydroxide } \\
\text { Hydrate }\left\{\mathrm{K}_{3} \mathrm{~W}_{6} \mathrm{FeO}_{20}(\mathrm{OH})\left(\mathrm{H}_{2} \mathrm{O}\right) 12\right\}\end{array}$ & $04-018-3781$ \\
\hline Shudha Shanka & Argonite $\left\{\mathrm{CaCO}_{3}\right\}$ & 01-085-6704 & Barium Anitomy Indium Oxide $\left\{\mathrm{Ba}_{2} \mathrm{InSbO}_{6}\right\}$ & 00-052-0005 \\
\hline Shanka Bhasma & $\begin{array}{c}\text { Calcite }\left\{\mathrm{CaCO}_{3}\right\} \\
\text { Portlandite }\left\{\mathrm{Ca}(\mathrm{OH})_{2}\right\} \\
\text { Lime }\{\mathrm{CaO}\}\end{array}$ & $\begin{array}{l}01-083-4620 \\
01-083-4600 \\
04-005-4398\end{array}$ & $\begin{array}{c}\text { Cobalt Tantalum }\left\{\mathrm{CoTa}_{2}\right\} \\
\text { Iron Oxide }\left\{\mathrm{Fe}_{3} \mathrm{O}_{4}\right\} \\
\text { Iron Palladium }\{\mathrm{FePb}\} \\
\text { Nickel Tin Titanium }\{\mathrm{TiNiSnO}\} \\
\text { Megnisium Rhenium Sulfide }\left\{\mathrm{MgRe}_{3} \mathrm{~S}_{4}\right\} \\
\end{array}$ & $\begin{array}{l}00-025-0255 \\
04-009-6242 \\
04-018-5488 \\
04-022-6675 \\
04-018-0735 \\
\end{array}$ \\
\hline
\end{tabular}

Table-7: Crystal geometry of samples

\begin{tabular}{|c|c|}
\hline Sample & Crystal Shape \\
\hline Raw Shankha & Orthorhombic cell. \\
\hline Shudha Shanka & Orthorhombic cell \\
\hline Shanka Bhasma & Hexagonal cell \\
\hline
\end{tabular}

\section{Micro metrics}

Initial sample of Shanka, have a crystal size of 255.7 A. Crystal lattice of this mineral having orthorhombic crystal system. This calcium carbonate compound is called Argonite. Aragonite is most naturally occurring form of calcium carbonatecontaining minerals [23]. Shodhana process might destruct the existing crystalline geometry and reduce the volume of unit crystal to 219.4 A. Finished formulation is called Shanka Bhasma, it was formed by thermal treatment of $800-1000{ }^{\circ} \mathrm{C}$. Argonite is mainly converted into Calcite having a crystal size of 62-90 A. Small size of crystal favor conversion of smaller particle size. The crystalline size of all samples was calculated by the Debye-Scherrer formula [24].

$$
L=\frac{k \lambda}{\beta \cdot \cos \theta}
$$

Where $\mathrm{L}$ is crystalline size; $\lambda$ is the $\mathrm{X}$-ray wavelength in nanometer; $\beta$ is the peak width of the diffraction peak profile at half maximum height resulting from the small crystalline size in radians and $\mathrm{k}$ is a constant related to crystallite shape; generally taken as 0.9 .

Table-8: Particle morphology and surface topography of sample shown by SEM-EDAX

\begin{tabular}{|c|c|}
\hline Sample & Shape \& features of Particle \\
\hline Raw Shankha & The acicular appearance of a particle having columnar habitat arrange in a parallel manner. \\
\hline Shudha Shanka & The acicular appearance of a particle having with slight disturbance of columnar arranges. \\
\hline Shanka Bhasma & Granular particle irregular morphology with smooth margins and corners \\
\hline
\end{tabular}

\section{Results of SEM-EDAX analysis}

Values of elemental composition of all samples were illustrated in following 3 tables.

Table-9(a): Elemental compositions of conch shell detected by EDAX

\begin{tabular}{|c|c|c|c|c|c|c|c|}
\hline \multirow{2}{*}{ Spectrum } & \multicolumn{2}{|c|}{ Calcium } & \multicolumn{2}{c|}{ Carbon } & \multicolumn{2}{c|}{ Oxygen } & \multirow{2}{*}{ Ratio of wt. of element } \\
\cline { 2 - 7 } & Wt \% & At \% & Wt \% & At \% & Wt \% & At \% & \\
\hline Point 1 & 27.29 & 12.24 & 16.16 & 24.2 & 56.55 & 63.56 & $1.7: 1: 3.5$ \\
\hline Point 2 & 25.86 & 11.46 & 16.78 & 24.83 & 57.37 & 63.71 & $1.5: 1: 3.4$ \\
\hline Point 3 & 27.29 & 12.24 & 18.75 & 29.83 & 49.37 & 51.35 & $1.5: 1: 2.6$ \\
\hline Mean & 26.81 & 11.98 & 17.23 & 26.29 & 54.43 & 59.54 & $1.6: 1: 2.0$ \\
\hline Std Devi & 0.82 & 0.45 & 1.35 & 3.08 & 4.40 & 7.093 & \\
\hline
\end{tabular}

Table-9 (b): Elemental compositions of Purified Conch Shell detected by EDAX

\begin{tabular}{|c|c|c|c|c|c|c|c|}
\hline \multirow{2}{*}{ Spectrum } & \multicolumn{2}{|c|}{ Calcium } & \multicolumn{2}{c|}{ Carbon } & \multicolumn{2}{c|}{ Oxygen } & \multirow{2}{*}{ Ratio of wt. of element } \\
\cline { 2 - 7 } & Wt \% & At \% & Wt \% & At \% & Wt \% & At \% & \\
\hline Point 1 & 25.81 & 11.25 & 25.26 & 36.75 & 47.25 & 51.6 & $1.0: 1: 1.8$ \\
\hline Point 2 & 30.79 & 14.79 & 14.22 & 21.97 & 54.99 & 63.78 & $2.0: 1: 3.9$ \\
\hline Point 3 & 27.25 & 12.43 & 16.04 & 24.09 & 56.33 & 63.49 & $1.7: 1: 3.4$ \\
\hline Mean & 27.95 & 12.82 & 18.50 & 27.60 & 52.85 & 59.62 & $1.5: 1: 2.8$ \\
\hline Std Devi & 2.56 & 1.80 & 5.91 & 7.99 & 4.90 & 6.94 & \\
\hline
\end{tabular}




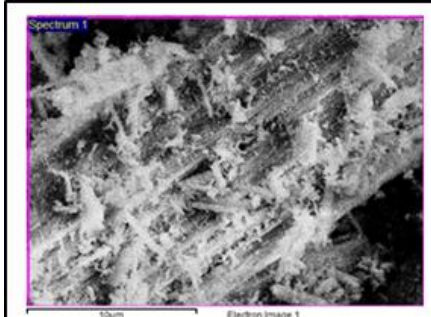

Conch Shell

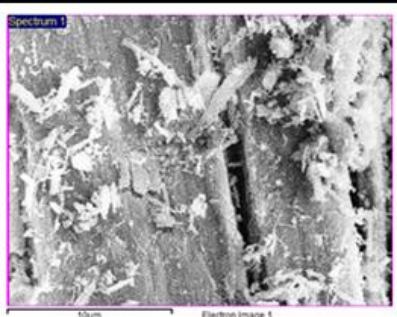

Purified conch Shell

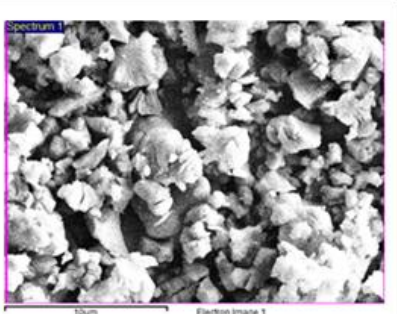

Conch Ash

Fig 3: Surface Microphotograph (SEM) of all samples of Conch

Table-9(c): Elemental compositions of Conch shell Ash detected by EDAX

\begin{tabular}{|c|c|c|c|c|c|c|c|}
\hline \multirow[t]{2}{*}{ Spectrum } & \multicolumn{2}{|c|}{ Calcium } & \multicolumn{2}{|c|}{ Carbon } & \multicolumn{2}{|c|}{ Oxygen } & \multirow[t]{2}{*}{ Ratio of wt. of element } \\
\hline & Wt \% & At $\%$ & Wt \% & At $\%$ & Wt \% & At $\%$ & \\
\hline Point 1 & 45.42 & 27.19 & 5 & 9.98 & 41 & 61.49 & $9.0: 1: 8.2$ \\
\hline Point 2 & 44.13 & 23.57 & 3.76 & 6.69 & 52.11 & 69.73 & $11.7: 1: 13.9$ \\
\hline Point 3 & 37.36 & 18.9 & 4.03 & 6.8 & 58.61 & 74.29 & $9.3: 1: 14.5$ \\
\hline Mean & 42.30 & 23.22 & 4.26 & 7.82 & 50.57 & 68.50 & $9.9: 1: 11.9$ \\
\hline Std Devi & 4.32 & 4.15 & 0.65 & 1.86 & 8.90 & 6.48 & \\
\hline
\end{tabular}

\section{Results of FT-IR Analysis}

FTIR spectroscopy was employed to get information on the structure, conformation of molecules and surface chemistry of particles.

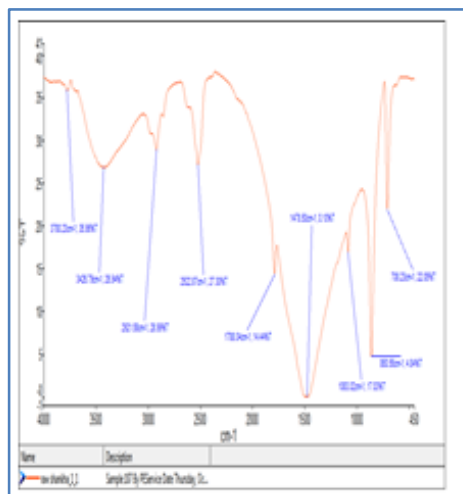

Couch Shell

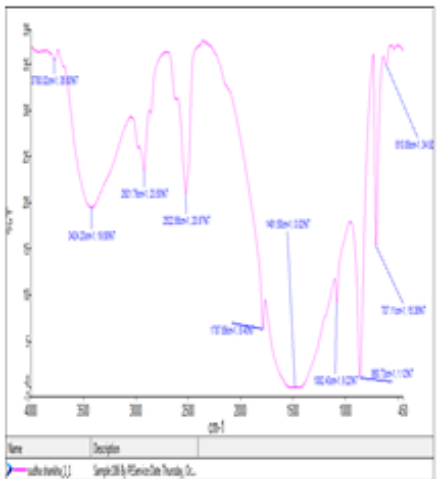

Purified conch shell

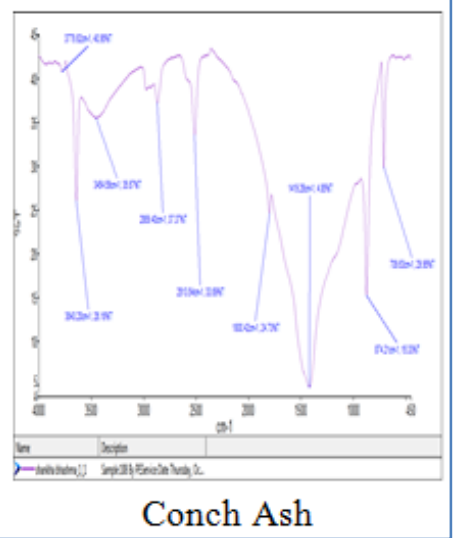

Conch Ash

Fig-4: FTIR Spectra of all samples of conch

Table-10: FTIR frequency wave number $\&$ its assignment of samples

\begin{tabular}{|c|c|c|}
\hline \multicolumn{3}{|c|}{ Vibrational Frequency } \\
\hline Raw Shankha & Shudha Shankha & Shankha Bhasma \\
\hline 3780 & 3780 & 3779 \\
\hline & & 3643 \\
\hline 3426 & 3424 & 3454 \\
\hline 2921 & 2921 & 2869 \\
\hline 2522 & 2522 & 2513 \\
\hline 1788 & 1787 & 1800 \\
\hline 1478 & 1481 & 1419 \\
\hline 1083 & 1082 & \\
\hline 860 & 860 & 874 \\
\hline 708 & 707 & 709 \\
\hline & 610 & \\
\hline
\end{tabular}

\section{DISCUSSION}

Discussion on Conch Ash formulation: In the formulation of Conch Ash various views, methods are mentioned in the Ayurvedic text. In this study, liquid media for Shodhan (purification) by steam baking was lemon juice due to the later described reason. A clinical study performed to evaluate the role of Conch Ash in the treatment of Gastro-esophageal reflux disorder (GERD) reveals that conch shell purified by lemon juice was more significant than Kanji (Sour gruel)[25]. Moreover, it reduces the chance of contamination and the addition of foreign material into the formulation. The third most crucial fact is that the modern studies show that bioavailability of calcium has more in citrate 
form than carbonate form [26]. The chemical reaction between citric acid and malic acid to calcium carbonate occurs spontaneously. In Marana (incineration) Aloe vera is prevalent media for wet levigation of conch and other Sudha Varga material. Aloe vera has silicate, and other elements in trace amount could interfere with the formation of citrate, and none of the studies was performed by taking lemon juice as media for wet levigation so far in this kind of research.

For Bhasmikaran in puta the maximum temperature $1007 \circ \mathrm{C}, 1012^{\circ} \mathrm{C}$ and $1006^{\circ} \mathrm{C}$ were found in $1^{\text {st }}, 2^{\text {nd }}, \& 3^{\text {rd }}$ puta respectively during incineration. This is very higher in comparison to the finding of Sandeep et al., which is $892^{\circ} \mathrm{C}-978^{\circ} \mathrm{C}$ [27]. In another thermo graphic study on puta, the maximum temperature was $846.33^{\circ} \mathrm{C}$ in a cubical pit and $861^{\circ} \mathrm{C}$ in a cylindrical pit. Despite the low volume of cylindrical pit peak temperature was found 10 minutes earlier. Weight of cow dung cake is required to fill the pit in cubical Gajaputa was $23.5 \mathrm{~kg}$ and in cylindrical Gajaputa was $16.6 \mathrm{~kg}$. [28]. However, here in this study, $50 \mathrm{~kg}$ cow dung cakes were used to make tetrahedral shape over the open surface of the pit. Average weight of cow dung cakes was 350 gms and in every cycle of incineration about 135-148 number of cow dung were used. Further, this study was conducted in the month of June and July. Variation of weight and shape of a cow dung cake, operating season and quantity of tradition fuel used may the plausible cause of this dissimilarity of temperature pattern of the operating pit. In this preparation, raw material, Conch was synthesized into its micro- to nano-sized medicine. However, the major phase of the material also change which was enlightened by XRD study. The transformation of aragonite began at $300-373^{\circ} \mathrm{C}$ and at $600-700^{\circ} \mathrm{C}$; the complete removal of volatile substances occurred, [29] and the phase transformation of aragonite to calcite was completed with a weight loss of $33.26 \%$ (2.63\% wt. loss during purification and $33.63 \%$ wt. loss during incineration) of the initial weight of the sample. The organic nacreous layer of Conch shell which is incorporate conchiolin and $\beta$ chitin that is sandwiched between glycine and alnine rich protein might be decomposed during incineration. This affirmation is shown by comparing the average ratio of $\mathrm{Ca}, \mathrm{C}$ and $\mathrm{O}$ that was shown in table 9(a), 9(b) and 9 (c). The carbon was reduced to six times than initial value. In purification, water-soluble and mild acidic reactant, impurities might be removed. These results also demonstrate that in the first incineration volatile matter decompose maximum, which was 23.74 $\%$ subsequently rate of decomposition decreases 18.75 $\%$ in second incineration and $16.88 \%$ in the third incineration.

Discussion on characterization of Conch Ash: Bhasma Parikasha (Ancient Ayurvedic technique of Bhasma analysis) and organoleptic evaluation has significant importance in quality control.
The high $\mathrm{pH}$ (12.8) not only favors dissolution under gastric condition but also neutralize the excessive $\mathrm{H}^{+}$ion present in the gaster. So the maximum amount of the absorption starts just after a few minutes of ingestion of the drug. The alkaline concentration may be attributed to the various amount of calcium oxide in its aqueous solution. The low value of Loss on drying $(0.45 \%)$ is preferable as it indicates low moisture content, greater shelf life \& durability. A high-value is accountable for hydrolysis of preparation, microbial and fungal growth. So this indicated that the drug has a longer shelf life. Total ash value (37.29\%) was very near to the quantity of calcium in the formulation. The finished formulation was mainly of lime and other very minute inorganic elements. Thermal decomposition of $\mathrm{CaCO}_{3}$ requires $600^{\circ} \mathrm{C}$, but in this only $450^{\circ} \mathrm{C}$ temperature was given. Therefore, partial decomposition of Bhasma, removal of volatile compounds might have occurred. The low value of Acid insoluble Ash $(0.96 \%)$ ash suggested that very minute part of conch. Ash digested in the GIT, but the ionic nature of formulation facilitates quicker dissolution. Although the value of Water-soluble ash is $3.02 \%$, which was more than four times of AIA, So the formulation could be readily soluble in water. The result of quantitative elemental determination in percentage shows that calcium in the sample was $39.3 \%$. This value was also equivalent to WSA. Similar result was also gets on elemental detection by EDAX was $42.30 \%$ by atomic value. In Particle size estimation the prepared Conch Ash qualified the test as $96.19 \%$ passed through the 100 number sieve. Also, SEM analysis showed that the finished product had particle size of agglomeration within the micrometer range. Though, the SEM micrograph reveals that it was in nano-size range. The smaller particle may facilitate quick absorption and assimilation of formulation in the gastrointestinal system. The data obtained by AAS shows that, all four heavy metal were found within the permissible limit. So, the Conch Ash is considered as safe for internal administration.

The FTIR spectral data obtained for the samples reveal a broad characteristic absorption peak of $\mathrm{CO}_{3}{ }^{2-}$ are divided into 4 areas: $v 1$ (symmetric stretching) at $1080-1084 \mathrm{~cm}^{-1} ; v 2$ at (out of- plane bending) 858- $874 \mathrm{~cm}^{-1}$; at $\mathrm{v} 3$ (doubly degenerates planar asymmetric stretching) $1400 \mathrm{~cm}^{-1}$ and $v 4$ (doubly degenerate in planar bending) at 707-709 $\mathrm{cm}^{-1}$ [30] but the high-temperature thermal treatment of conch shell during incineration leads to conversion of Aragonite form into metastable form calcium carbonate, i.e., Calcite [31] by some plausible internal changes of reorganization \& orientation of carbonate in molecule structure. 9 peaks of graphs was very much similar in couch shell and purified conch, only one extra peak appeared at $610 \mathrm{~cm}-1$ in purified Conch. Moreover, In Conch Ash peak at $3643 \mathrm{~cm}-1$ was arises while a characteristic peak of carbonate at $1083 \mathrm{~cm}-1$ was not visible. Moreover, the peak at $3643 \mathrm{~cm}-1$ shows the 
presence of Hydroxyl [-OH] functional group and water in hydrated form. Phase analysis by XRD shows that Potlandite $\left[\mathrm{Ca}(\mathrm{OH})_{2}\right]$ and Lime $[\mathrm{CaO}]$ is in small amount in conch Ash. The operating conditions such as $\mathrm{pH}$, temperature and treating media could favor the nucleation and growth of a metastable polymorph [32]. Diagnostic peaks were therefore $709 \mathrm{~cm}^{-1}$ for calcite and $1083 / 1082 \mathrm{~cm}^{-1}$ and $860 \mathrm{~cm}^{-1}$ for Aragonite. Vibrational Peaks of either bending or stretching over $1419 \mathrm{~cm}^{-1}$ in every sample shows the presence of other functional groups.

The influence of organic additives of lemon juice as intermediate media during purification \& trituration treating media may influence on the nucleation and crystal growth rates and its polymorphic forms. This is observed in altered morphology and particle size. It was thought to be caused by a reaction with carboxyl groups of citric acid. Citric Acid is an organic tri-acid (it has three carboxylic acid groups) that is fairly soluble in cold water. Citric acid is more acidic than carbonic acid and can react with carbonates to release carbon dioxide and water $\left(\mathrm{CO}_{2}+\mathrm{H}_{2} \mathrm{O}\right)$. Citric acid can undergo acid-base reactions with other salts to form citrate salts.

$$
\mathrm{CaCO}_{3}+\mathrm{C}_{6} \mathrm{H}_{8} \mathrm{O}_{7} \rightarrow \mathrm{Ca}\left(\mathrm{C}_{6} \mathrm{H}_{6} \mathrm{O}_{7}\right)+\mathrm{H}_{2} \mathrm{O}+\mathrm{CO}_{2} \text { (gas) } \uparrow
$$

- $\mathrm{COOH}$ groups and -OH group of citric acid is very near to each other - it can fold in space to envelop the metal ion as at least tridentate ligand. In many cases, citrate ligand acts like a "chelating ligand", meaning that citrate ligand holds on to the calcium with multiple points of attachment. In general, the more of conveniently placed electronegative atoms with free electron pairs - mainly $\mathrm{O}$ and $\mathrm{N}$, or for "noble" metals, here $\mathrm{Ca}$; the better the chelate agent - it is quite intuitive that things that bind to metal through more atoms, bind more strongly. Further, Calcium citrate is sparingly soluble in water. Onward the formation of calcium citrate, the mechanism of monolayer adsorption of Calcium citrate molecules on $\mathrm{CaCO}_{3}$ particles surface occurred. Ultimately formation of a layer of calcium citrate, which acts as a surfactant, improving the dispersibility and lowering their agglomeration [33].

However, it is slightly more soluble in water as compared to calcium carbonate. In addition to this fact, the hardness of Conch Shell (Aragonite- 3.5 to 4 Mohs) is reduced in the final formulation (Calcite 3 Mohs)[34]. It was observed during the pharmaceutical study that after purification conch shell becomes soft and also after Puta process pellets become softer and very fragile.

\section{CONCLUSION}

Conch is biogenic material of marine origin used in Ayurveda since Samhita age. It is used in the treatment of the disease of various system of the body with different Anupana (vehicle drugs). However, it is used in the treatment of GIT diseases very frequently. Conch Bhasma is the main ingredient of many Ayurvedic Formulations. Madhur \& Kashya - Rasa and Sheeta virya (Cool property after ingestion) help to cure Amla-pita (dyspepsia) by acid-neutralizing property of $\mathrm{Ca}^{2+}$. Probably, Astringent Taste and Grahi - Guna (absorbing capability) along with Anti-inflammatory feature of $\mathrm{Ca}^{2+}$ may be accountable in curing Grahini (Irritable bowel disease/ Tropical Sprue). Easy availability, low market price and technico-economical pharmaceutical operation are responsible factor for its popularity. Lemon juice used in processing removes the impurities and reduces the alkalinity by acidulant nature in the final formulation. The citric acid present in Lemon quickly reacts with calcium, which improves its absorption within the biological system. Thermal treatment in an incineration pit at $500-900^{\circ} \mathrm{C}$ not only removes $\mathrm{S}, \mathrm{N}, \mathrm{C}, \& \mathrm{P}$ but also, decomposes most of the organic matter into gaseous form. This also decreases the dimension of the crystal size of the molecule. Shikharakar Gajaputa generates more heat energy than normal Gajputa. This tedious and unique processing converts the all polymorph of calcium carbonate into metastable Calcite form. 60 - $100 \mathrm{~nm}$ Nano-sized particles of formulation emphasis its easy assimilation during digestion. Undoubtedly, Bhasmikaran is the most ancient method of synthesis of nano-sized particle of calcium carbonate through the top-down technique. Certainly, crystalline nature and single compound of the formulation could be utilized into the preparation of newer dosage of it, namely suspension, tablet and syrup comfortably.

\section{REFERENCES}

1. Shastri, K.N., \& Chaturvedi, G.N. (2005). Hindi commentary on Charka Shamhita Part 1, Sutrasthana Chaukhambha Bharti academy, Varanasi, Edition-2005, verse-1/68, pp-41.

2. Chavan, S., Tayade, S., Gupta, V., Deshmukh, V., \& Sardeshmukh, S. (2018). Pharmaceutical Standardization and Physicochemical Characterization of Traditional Ayurvedic Marine Drug: Incinerated Conch Shell (Shankha Bhasma). Marine drugs, 16(11), 450.

3. Nadkarni, K. M., Dr. K. M. (1994). Nadkarni's Indian Materia medica. Turbinella Rapa; or Xanchus Pyrum or Gastropoda, Class: Mollusca. Popular Prakashan. Edition, 164-165.

4. Krishna, N. (1980). The art and iconography of Vishnu-Narayana. DB Taraporevala.

5. Yadevendra, Y., Sani, S., Sharma, K. C., Hema, P., \& Rajesh, A. K. (2019). A novel ayurvedic techniques approach for value addition of waste materials.

6. Reddy, K.R.C.(2007). Ocean of Ayurvedic Pharmaceutics, Chaukhambha Sanskrit Bhawan: Varanasi; 1st edition.

7. Anonymous. (1978). The Ayurvedic Formulary of India, Part I. 
8. Shastri, K. (2004). Hindi commentary of Rasa Tarangini of Sadanand Sharma, 11th edition 2004, Motilal Banarsidas. New delhi, Taranga-12/619.pp-285-288

9. Meena, M., Sharma, R. (2013). Ayurvedia Rasa Shastra, Ayurveda Sanskrit hindi pustak bhandar, Jaipur India, $1^{\text {St }}$ Edition, 421.

10. Bhagwat, M. (2004). Preparation and physico chemical characterization of the bhasmas of zinc and calcium and the Intermediates obtained during their synthesis.

11. Leng, Y. (2009). Materials characterization: introduction to microscopic and spectroscopic methods. John Wiley \& Sons.

12. Shastri, K. (2004). Hindi commentary of Rasa Tarangini of Sadanand Sharma, 11th edition 2004, Motilal Banarsidas. New delhi, Taranga-2/52, 22.

13. Shastri, K. (2004). Hindi commentary of Rasa Tarangini of Sadanand Sharma, 11th edition 2004, Motilal Banarsidas. New delhi, Taranga-2/49.pp21.

14. Shastri, A. (2015). Rasaratnasamuccaya, Chowkhamba Amarbharti Publication; $10^{\text {th }}$ Edition 2015 Varanasi (India), verse-10/47.

15. Kulkarni, D. A.(2006). Rasaratansamuccaya, vijnana Boddhini commentary, Meharchand Laxmandas Publication, Newdelhi, Edtion-2006, verse- 10/53-54, pp-188-189.

16. Sarkar, P.K., \& Chaudhary, A.K. (2010). Ayurvedic Bhasma: The most ancient application of nanomedicine, Journal of scientific and industrial research, 69(12), 901-05.

17. Vilegave, K., Vidyasagar, G., \& Chandankar, P. (2013). Preformulation studies of pharmaceutical new drug molecule and products: An Overview. American journal of pharmacy and health research, 1(3), 1-20.

18. Annonymous, Protocol for testing Ayurvedic, Siddha, \& Unani Medicines, Ministry of Ayush, government of india pharmacopoeial laboratory for indian medicines, Ghaziabad, $1^{\text {st }}$ Edition, 31.

19. Annonymous.(2008). The Ayurvedic pharmacopoeia of India,Government Of India, Ministry of health and family welfare, Department of Ayurveda, Yoga \& Naturopathy, Unani, Siddha and Homoeopathy, New Delhi, 1st Edition, Part II, (I), 10:10, 133.

20. Annonymous. (2008). The Ayurvedic pharmacopoeia of India, Government of India, Ministry of health and family welfare, Department of Ayurveda, Yoga \& Naturopathy, Unani, Siddha and Homoeopathy, New Delhi, 1st Edition, Part II(I), 10:10, 80-84.

21. Annonymous. (1987). Pharacopeial standards for Ayurvedic formulations, Central council for research in Ayurveda \& Siddha, New Delhi, 1st Edition, 488-496.

22. Annonymous. (1987). Pharacopeial standards for Ayurvedic formulations, Central council for research in Ayurveda \& Siddha, New Delhi, 1st Edition,-53.

23. https://en.wikipedia.org/wiki/Aragonite, visited 12.12.2019.

24. Patterson, A. (1939). "The Scherrer Formula for X-Ray Particle Size Determination". Phys. Rev. edition, 56(10), 978-982.

25. Ranade, M., \& Chary, D. L. (2013). Comparison of two purification products of shankha bhasma: A prospective randomized control trial. Journal of natural science, biology, and medicine, 4(1), 160.

26. Shankar, K., Sakthibalan, M., Raizada, P., \& Jain, R. (2018). A randomized open-label clinical study comparing the efficacy, safety, and bioavailability of calcium lysinate with calcium carbonate and calcium citrate malate in osteopenia patients. Journal of orthopaedic case reports, 8(4), 15.

27. Chavan, S., Tayade, S., Gupta, V., Deshmukh, V., \& Sardeshmukh, S. (2018). Pharmaceutical Standardization and Physicochemical Characterization of Traditional Ayurvedic Marine Drug: Incinerated Conch Shell (Shankha Bhasma). Marine drugs, 16(11), 450.

28. Chaterjee, I. (2013). Determination of fuel and temperature in various Putas W.S.R. Rasa Ratna Sammuchaya, Master's thesis, Rishikul Ayu. College, Haridwar, India.

29. Shafiu Kamba, A., Ismail, M., Ibrahim, T., Azmi, T., \& Zakaria, Z. A. B. (2013). Synthesis and characterisation of calcium carbonate aragonite nanocrystals from cockle shell powder (Anadara granosa). Journal of Nanomaterials, 2013.

30. Zhang, Z., Xie, Y., Xu, X., Pan, H., \& Tang, R. (2012). Transformation of amorphous calcium carbonate into aragonite. Journal of Crystal Growth, 343(1), 62-67.

31. Udrea, I., Capat, C., Olaru, E. A., Isopescu, R., Mihai, M., Mateescu, C. D., \& Bradu, C. (2012). Vaterite synthesis via gas-liquid route under controlled $\mathrm{pH}$ conditions. Industrial \& engineering chemistry research,51(24), 8185 8193.

32. Yamanaka, S., Ito, N., Akiyama, K., Shimosaka, A., Shirakawa, Y., \& Hidaka, J. (2012). Heterogeneous nucleation and growth mechanism on hydrophilic and hydrophobic surface. Advanced Powder Technology,23(2), 268-272.

33. Croitoru, C., Pascu, A., Roata, I. C., \& Stanciu, E. M. (2017, June). Obtaining and characterization of polyolefin-filled calcium carbonate composites modified with stearic acid. In IOP Conference Series: Materials Science and Engineering. IOP Publishing, 209(1), 012041

34. Dana, J. D., Klein, C., \& Hurlbut, C. S. (1985). Manual of Mineralogy, Wiley, 329. 